\title{
Impact of Employees' Attitudes and Leader's Role on the Innovation Management Linked to Social Responsibility
}

\author{
DOI: 10.12776/QIP.V22I2.1121
}

Mauricio Antonio Bedoya-Villa, Manuela Escobar-Sierra

Received: 07 June 2018

Accepted: 30 June 2018

Published: 31 July 2018

\begin{abstract}
Purpose: The innovation management linked to social responsibility is considered a strategy of organizational growth promoted by the creativity of employees framed in economic, ethical and legal issues. This study analyses socially responsible innovation management base on employee's attitudes and leader's role, from a case study of a company in the Colombian automotive sector.
\end{abstract}

Methodology/Approach: We began with the review of theories about innovation and social responsibility. Then we collected data through creative techniques, surveys to classify the leader's role, attitudes scale, participant observation and interviews. To finally analyse data with multiple linear regression and other techniques, such as decision trees.

Findings: Finally, the initial concept of socially responsible innovation and its management is complemented by five self-determined employees' attitudes, and one behavior and three perceptions of the leader.

Research Limitation/implication: The choice of the single case study as a research strategy determines the practical scope of the research as analytical. In this sense, the need to replicate the study and analyse the impact of other personal and organizational factors is highlighted.

Originality/Value of paper: It is important to summarise the value of our paper, in relation to the following aspects: the opportunity that represents for companies the correct socially responsible innovation management, the importance of the Enterprise-University integration and, finally, the relevance of hybrid models in this case, a multiple linear regression and decision trees.

Category: Case study 
Keywords: innovation; social responsibility; employees' attitudes; leader's role; multiple linear regression; decision trees; case study of a company in the Colombian automotive sector

\section{INTRODUCTION}

Some authors recognize the innovation management linked to social responsibility (SR) as a strategy of organizational growth, promoted by the creativity of employees framed in economic, ethical and legal issues. In this context, and after recognizing the need to manage SR-linked innovation, in an empirical context that benefits sustainability at an organizational level (EscobarSierra, 2015; Escobar-Sierra and Vera-Acevedo, 2016), arise the following question: How do the employees'attitudes and leader's role impact the innovation management linked to SR? To find the answer for this, we chose a company from the Colombian automotive sector as the research field. A series of regional, national and sectoral dynamics explain the empirical relevance of this selection. Among the aforementioned dynamics, the following are considered: (1) the high mortality rate of the companies constituted in the region, this as a consequence of the poor value creation (Cámara de comercio de Medellín para Antioquia, 2013). (2) The predominance of internal idea generation process in Colombian enterprises (DANE, 2015). (3) The lack of innovation management activities in the automotive sector, where the priority has been the enterprise itself, excluding the market (DANE, 2015). And finally (4) a marked decrease in the employment rate of the sector (Programa de Transformación Productiva, 2015).

When verifying the theoretical framework available around the research question, several studies are reviewed, to finally confirm the need to articulate the findings on employees'attitudes, leader's role, innovation and SR. Among these studies, Hashimoto and Nassif (2014) can be mentioned, who "through an empirical study" stressed that the attitude and, in general terms, the role of a leader is critical when referring to the innovation strategy. Corbett, et al. (2013) also specified the individual traits of the employees and of the managers as one of the future lines of the study on innovation and corporate entrepreneurship. Lau, et al. (2012), when analysing the behavior of managers, stress attitudes as essential for innovation. Castrogiovanni, Urbano and Loras (2011) examined which human resource management practices impact innovation, in order to highlight the importance of personal relationships and the need to analyse the impact of attitudes, decision-making and context. Finally, Urbano, Toledano and RibeiroSoriano (2011) analysed human resource management practices verifying the importance of establishing good relationships among employees, the creation of an adequate work environment and the importance of promoting risk attitudes and employee participation. Once the theoretical relevance of the project has been verified, the socially responsible innovation is selected as the theoretical framework of the study (Escobar-Sierra, 2015). This concept "i.e. socially 
responsible innovation" is a recently conceptualized term in which innovation is linked to corporate social responsibility (CSR).

In this context, and from a quantitative approach to science, a particular case study is adopted as a research strategy (Yin, 1992). The choice of this research strategy is justified with the later study of the same author (Yin, 2002), who recognizes the importance of this type of approach in contexts such as that reviewed "where the researchers are trying to: (1) test a theory, (2) represent an extreme and unique case, (3) symbolize a typical case, (4) become a revealing case or (5) match a conditional case". On the other hand, for the analysis of the collected data, a hybrid model is proposed with statistics and data mining (multiple linear regression and decision tree). This model allows the verification of the relationship between socially responsible innovation, employees' attitudes and leader's role.

Finally, the integrity and significance of the research is verified through the checklist proposed by Creswell, et al. (2011), to finally conclude how employees' attitudes and leader's role explain the innovation management linked to SR. This finding has an analytical scope at a practical level "justified by the selected research strategy". While at the theoretical level, it complements the initial conceptualization of socially responsible innovation (SRI) (Escobar-Sierra, 2015; Escobar-Sierra and Vera-Acevedo, 2016) and its management based on five self-determined employees' attitudes, one type of behavior and three perceptions about the leader's role. The five self-determined attitudes are: (i) the importance of others' approval, (ii) the perceived success based on the objectives, (iii) the unconditional love of the family, (iv) the acceptance of criticism and (v) the impossibility of feeling equal to the others. Furthermore, the one type of behavior includes (a) agreement between a leader's values and way of acting, and the three perceptions include (I) the leader's perception in terms of completion of the beginning tasks, (II) control of emotions and (III) interest in others. To finally, alert about how the results correspond with the previous recommendations of authors such as Castrogiovanni, Urbano and Loras (2011), Corbett, et al. (2013), Hashimoto and Nassif (2014) and Lau, et al. (2012), and with gap identified by Marinova and Phillimore (2003), in the last generation of innovation.

\section{LITERATURE REVIEW AND SELECTION OF THE THEORETICAL FRAMEWORK}

To select the theoretical framework of the study, we take some previous theories about innovation and SR as the starting point. For the innovation case, the theoretical proposal by Marinova and Phillimore (2003) is selected as a starting 
point. They "i.e Marinova and Phillimore (2003)" present the following six generations when referring to innovation:

- The first generation or model of the black box, emphasizes autonomy and independence as essential (Merton, 1973). Under this generation, innovation is related to technological change (Beristain, 2009; Jardón, 2011; Rosenberg, 2000; Schumpeter, 1983; Teece, 2002), which does not include research and development processes, situations that promoted the formulation of the next generation.

- The second generation or linear model, integrates the first two innovation models proposed by Rothwell (1992) through a sequence of activities that promoted the market adoption of different technologies (Beije, 1998; Cooper and Cooper, 2003; Feldman, 1994; Freeman, 1982; Hadjimanolis, 2003; Méndez, 2002; Rothwell and Zegveld, 1985). This generation was replaced by alternative concepts like funding for researchers.

- The third generation or interactive models, adopt the third and fourth model proposed by Rothwell (1992) and introduce innovation as an iterative circular process (Beije, 1998; Dodgson and Bessant, 1996; Kline and Rosenberg, 1986), in which multiple interactions are presented. This model is debated because it does not explain how an organization learns in the environment.

- The fourth generation or systems model, proposes an adaptation of the fifth model proposed by Rothwell (1992), in which the cooperation between firms is highlighted (Hobday, 1991; Marceau, 1992; Sako, 1992). The best-known model of this generation is the 'National Innovation System' (Dodgson, 1993; Freeman, 1991; Gann, 2003; Lundvall, 1992; Metcalfe, 1995; Nelson, 1993; 2000), which identifies gaps related to the role of government and regulations.

- The fifth generation or evolutionary model, stresses limited rationality (Dosi and Egidi, 1991) and the value of diversity (Dowrick, 1995) on the basis of the technological imperatives (Rosenberg, 1976), the avenues of innovation (Sahal, 1981), the technological trajectories (Biondi and Galli, 1992; Pavitt, Robson and Townsend, 1989), the technological (Dosi, 1982; 1988) and techno-economic paradigms (Freeman and Perez, 1988; Perez, 1983). These models have been questioned due to its predictive potential.

- The sixth generation or innovative model, defined innovation as a combination of generic knowledge and specific competencies, linked to the territorial organization (Bramanti and Ratti, 1997; Longhi and Keeble, 2000). Some of the concepts related to this generation are: innovation clusters (Porter, 1990), learning of the area (Florida, 1995; Kirat and Lung, 1999; Macleod, 1996; Simmie, 1997) and collective learning (Keeble, 2000; Lawson, 2000). The future of this model "the last one 
listed by Marinova and Phillimore (2003)" may be related to innovation and environment (Honkasalo, 2000).

For SR, the starting point is the proposal of Schwartz and Carroll (2003), who recognized the link between business and society (Klonoski, 1991), and the ambiguity surrounding SR. Schwartz and Carroll (2003) decided to reinterpret the previous proposal by Carroll (1979) and suggest a new model that tries to correct the opportunity areas of the first one, proposing how discretional expectations should be considered or included within ethical or economic responsibilities. They "i.e. Schwartz and Carroll (2003)" finally proposed a model defined with three domains (ethical, economic and legal) and graphically represented through a Venn diagram.

Regarding this, and after the theoretical review, SRI i.e. "socially responsible innovation" is chosen as the theoretical framework of the study (Escobar-Sierra, 2015). This term comes as a response to the gap identified by Marinova and Phillimore (2003) in the sixth generation of innovation "when referring to the importance of taking into account the environment", and also in line with the scope of the studies carried out by Guadamillas and Donate (2008), McFadzean, O'Loughlin and Shaw (2005) and Shaw, O'Loughlin and McFadzean (2005), when highlighting the importance of linking corporate entrepreneurship with innovation and SR. This term "i.e. SRI" has been recently adopted to link innovation with social responsibility, in a first case study, this term was defined by the intrinsic motivation of the employee and the use of knowledge (EscobarSierra, 2015).

\section{METHODOLOGY}

Next, in Tab. 1, the proposed protocol for the research is presented. It details the selected role for the theory, the conceptual framework guiding the study, the research question, the chosen strategy for the fieldwork, the analysis unit to be identified, the variables to be quantified, the data to be gathered, the type of analysis to be applied, the expected results and, finally, the definition of the ethical considerations to be guaranteed (Escobar-Sierra, 2015).

Table 1 - Research Protocol (Own Elaboration)

\begin{tabular}{|l|l|}
\hline & Quantitative Approach \\
\hline Role of the theory & Deductive \\
\hline $\begin{array}{l}\text { Theoretical } \\
\text { framework }\end{array}$ & Socially responsible innovation \\
\hline Research problem & $\begin{array}{l}\text { How the attitudes of employees and the role of a leader impact the } \\
\text { management of innovation linked to social responsibility? }\end{array}$ \\
\hline Research strategy & Particular case study \\
\hline Analysis unit & Attitudes and role of a leader \\
\hline
\end{tabular}

ISSN 1335-1745 (print) ISSN 1338-984X (online) 


\begin{tabular}{|c|c|}
\hline & Quantitative Approach \\
\hline Sample & 37 employees from the automotive sector \\
\hline Variables & $\begin{array}{l}\text { Dependent variable (a measure of adjustment or significance) and } \\
\text { independent variables (quality of the ideas related to the SR, attitude, } \\
\text { classification of the type of leader). }\end{array}$ \\
\hline $\begin{array}{l}\text { Techniques for } \\
\text { data collecting }\end{array}$ & $\begin{array}{l}\text { - Technique: creative and analytical techniques (Pernelle, et al., 2014; } \\
\text { Vieira, Alves and Duboc, 2012). } \\
\text { - Variables: quality parameter for ideas (Reinig and Briggs, 2013) } \\
\text { (Likert scale for SR criteria). } \\
\text { - Instrument: a survey to determine employees' attitudes. The warpy } \\
\text { thoughts scale (Parslow, et al., 2006) and a survey to classify the } \\
\text { type of leader (The 360-degree emotional competence profiler } \\
\text { (Wolmarans and Martins, 2001). }\end{array}$ \\
\hline Analysis of results & $\begin{array}{l}\text { - Multiple linear regression } \\
\text { - Decision tree }\end{array}$ \\
\hline Expected results & $\begin{array}{l}\text { - Attitude factors and the role of significant leaders in the quality of } \\
\text { the ideas generated. }\end{array}$ \\
\hline $\begin{array}{l}\text { Ethical } \\
\text { considerations }\end{array}$ & $\begin{array}{l}\text { - Agreement on the participation of ownership rights } \\
\text { - Confidentiality agreement }\end{array}$ \\
\hline
\end{tabular}

This protocol was applied during the fieldwork carried out in 2016. During this period, the described instruments were applied to employees from different areas of the automotive sector company.

\section{RESULTS AND ANALYSIS}

The results obtained with the described protocol, as well as its interpretation, are described below. Then, the research quality criteria proposed by Creswell, et al. (2011) are verified in the selected case study, to finally conclude with the discussion of the results with other authors.

\subsection{Results and Analysis of Multiple Linear Regression}

To place the results of the quantitative approach, it is pertinent to define the multiple linear regression technique as an statical analysis used to establish the relationship between (1) the dependent variable $(Y)$ "defined in this case study by the quality metric for ideas (Reinig and Briggs, 2013) (Likert scale for SR criteria)" and (2) the set of independent variables represented by $\left(x_{1}, x_{2}, \ldots x_{n}\right)$, "defined in this case study by the survey to determine employees' attitudes [The warpy thoughts scale (Parslow, et al., 2006)] and the survey to classify the type of leader [The $360^{\circ}$ emotional competence profiler (Wolmarans and Martins, 2001)]". Between the important features of the multiple linear regression analysis techniques, is its capability to fit with real situations (like those considered in this 
case study). These real situations can be explained by many variables that directly or indirectly affect the situation (Rodríguez and Mora, 2001).

Once the concepts to be implemented have been specified, the applied procedure for the automated linear modeling is described. During this process, a stepforward technique is applied, to select the significant effects with an accuracy level of $83.5 \%$. In Tab. 2, the resulting significant effects, for the employees'attitudes and the leader's role over the quality of the generated ideas, are presented.

Table 2 - Summary of Automated Linear Modelling (Own Elaboration with the SPSS® Software)

\begin{tabular}{|c|c|c|c|c|c|c|c|c|c|c|}
\hline & Step & & & & & & & & & \\
\hline & 1 & 2 & 3 & 4 & 5 & 6 & 7 & 8 & 9 & 10 \\
\hline Information criteria & 27,421 & 35,82 & 0,6 & 4,24 & 8,83 & 9,63 & 2,59 & 3,63 & 54,59 & 88,591 \\
\hline Approval_2_transformed & $\checkmark$ & $\checkmark$ & $\checkmark$ & $\checkmark$ & $\checkmark$ & $\checkmark$ & $\checkmark$ & $\checkmark$ & $\checkmark$ & $\checkmark$ \\
\hline $\begin{array}{l}\text { Exchange relations_ } \\
\text { criterion_38_perception }\end{array}$ & & $\checkmark$ & $\checkmark$ & $\checkmark$ & $\checkmark$ & $\checkmark$ & $\checkmark$ & $\checkmark$ & $\checkmark$ & \\
\hline $\begin{array}{l}\text { Self-motivation_criterion_ } \\
\text { 20_behavior_transformed }\end{array}$ & & & $\checkmark$ & $\checkmark$ & $\checkmark$ & $\checkmark$ & $\checkmark$ & $\checkmark$ & $\checkmark$ & $\checkmark$ \\
\hline $\begin{array}{l}\text { Need_for_success_12_ } \\
\text { transformed }\end{array}$ & & & & $\checkmark$ & $\checkmark$ & $\checkmark$ & $\checkmark$ & $\checkmark$ & $\checkmark$ & $\checkmark$ \\
\hline Effect love_6_transformed & & & & & $\checkmark$ & $\checkmark$ & $\checkmark$ & $\checkmark$ & $\checkmark$ & $\checkmark$ \\
\hline $\begin{array}{l}\text { Exchange_relations__ } \\
\text { criterion_33_perception_ } \\
\text { Transformed }\end{array}$ & & & & & & $\checkmark$ & $\checkmark$ & $\checkmark$ & $\checkmark$ & $\checkmark$ \\
\hline Approval_1_transformed & & & & & & & $\checkmark$ & $\checkmark$ & $\checkmark$ & $\checkmark$ \\
\hline $\begin{array}{l}\text { Need_for_success_11 } \\
\text { transformed }\end{array}$ & & & & & & & & $\checkmark$ & $\checkmark$ & $\checkmark$ \\
\hline $\begin{array}{l}\text { Emotional education } \\
\text { criterion_6_perception }\end{array}$ & & & & & & & & & $\checkmark$ & $\checkmark$ \\
\hline
\end{tabular}

By analysing and interpreting the effect of employees'attitude and leader's role factors over the quality of the generated ideas, the following is highlighted: (1) the remarkable incidence of self-determined factors of employee's attitudes over the quality of the generated ideas, where five of the nine significant effects referred to in Tab. 2 correspond to attitude issues. And (2) the prevalence of issues related to the perception of a leader's behaviors over the quality of $s$ the generated ideas, where four of the nine significant effects for a leader's role 
correspond to perceptual issues. Among the attitude factors that impact the quality of socially responsible ideas, the following are found: (i) the importance of others' approval, (ii) the perceived success based on the objectives, (iii) the unconditional love of the family, (iv) the acceptance of critics and (v) the impossibility of feeling equal to the others. On the other hand, when referring to the effects of leader's role over quality, is highlighted the effect of: (I) the concordance between the leader's values and the leader's way of act, (II) the leader's perception during the finalization of the initiated tasks, (III) leader's emotional control and (IV) leader's interest in others.

\subsection{Results and Analysis of the Decision Tree}

After reviewing the obtained results for the multiple linear regression through automated linear modeling, it is pertinent to define decision trees as a data mining technique developed from the ideas by Morgan and Sonquist (1963), where a non-parametric segmentation analysis is applied for exploratory purposes. Decision trees comprise an algorithm that allows the construction of contingency tables. These tables are developed from the classification of explanatory variables whose relationship with the response variable has been previously verified.

The decision trees can be applied as a prediction tool, in this case study decision trees would predict quality results for the generated ideas. To apply this data mining technique a procedure based on the CRT growth method was selected, configured with the quality dependent variable and the independent variables defined in the previous number (4.1) as significant effects of the employees'attitudes and the leader's role. Next, in Fig.1, the decision tree is presented for the significant factors that affect the quality of the ideas. 


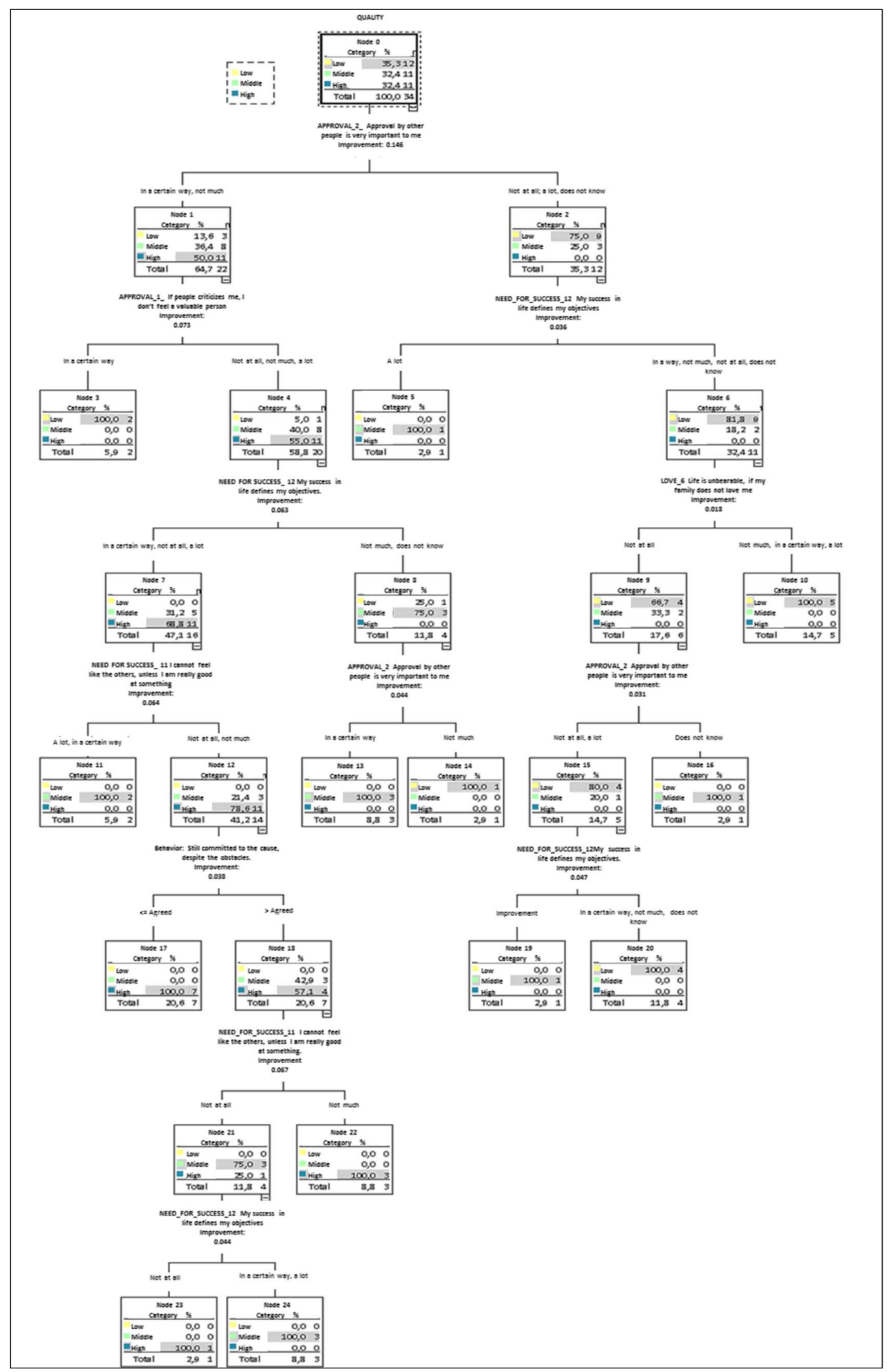

Figure 1 - Decision Tree for Significant Factors that Affect Idea Quality (Own Elaboration with the SPSS® Software) 
This decision tree Fig. 1 helps to predict, with a 50\% probability, the high quality of the ideas generated by employees who value others' approval in "a certain way or not so much". When considering the acceptance of critics, the high quality of the ideas can be predicted with a 55\% probability, when the employee is indifferent to critics. With a $68.8 \%$ probability, high quality for ideas generated can be predicted in employees with extreme positions about the fulfillment of the objectives. In this context, quality ideas stand out, with a probability of $78.6 \%$, among employees who feel like others. Meanwhile, high quality for the ideas generated by employees that identify commitment in the behavior of their leader is predicted with a $100 \%$ probability.

\subsection{Verification of Quality Criteria}

After evaluating the significance criteria "e.g. researchers, innovation, approach and the environment" proposed by Creswell, et al. (2011) in his checklist, an average score of 6.7 out of 10 possible points was obtained for the case study. This verification confirms the empirical as well as theoretical validity of the findings discussed below.

\subsection{Discussion of the Results Obtained}

This research project is based on the previously obtained results in a company from the Colombian graphics sector, where the impact of motivation and knowledge on innovation linked to CSR was evaluated (Escobar-Sierra, 2015; Escobar-Sierra and Vera-Acevedo, 2016). During this research, the SRI was conceptualized and in the future directions, issues like the inclusion of personality traits as well as the employees'attitudes and the leader's role on SRI has been mentioned.

In addition, and attending to the identified gap (Escobar-Sierra, 2015; EscobarSierra and Vera-Acevedo, 2016), the results confirm the suspicions of other authors such as (1) Bedoya, Toro and Arango (2017), Corbett, et al. (2013) and Hashimoto and Nassif (2014) when confirm the incidence of a leader's attitudes on the innovation strategy, in this case on the SRI. (2) Castrogiovanni, Urbano and Loras (2011) and Urbano, Toledano and Ribeiro-Soriano (2011) when relating the employees'attitudes with strategic organizational matters such as innovation. And finally, (3) Lau, et al. (2012) when underlining the importance of considering both "i.e. employees'attitudes and the leader's role" with innovation-related matters.

In this sense, the results have managerial implications because they corroborate how important it is to incorporate the role of a transformational leader and its influence on the employees' intellectual stimulation into management practices. 


\section{CONCLUSIONS AND RECOMMENDATIONS}

The obtained results from the quantitative approach of science serve to complement the preliminary conceptualization on SRI and its management. With this case, the SRI management is enriched with five of the self-determined employees'attitudes, one type of behavior and three perceptions about the leader's role. However, it is important to keep in mind that the choice of the single case study as a research strategy determines the practical scope of the research as analytical.

In this context, it is pertinent to summarise other findings related to (a) the lack of consensus and poor structuring around the SR policies, (b) the priority of the internal sources of ideation in the researched context, (c) the opportunity that represent the correct management of SRI as a strategic tool, (d) the importance of the Enterprise-University integration and, finally, (e) the relevance of hybrid models -multiple linear regression and decision trees-.

This research contains some limitations. The first one, related with the ideation process framed in economic, ethical and legal issues, because many times it is difficult for employees to generate innovative ideas that benefit the stakeholders and also respect the economic, ethical and legal issues. Second, CSR practices are discretional, a situation that does not provide sufficient evidence for judgment, because each company decides how to interpret and define its CSR practices. These situations make difficult to establish a pattern to measure organizational performance.

Finally, for future studies about SRI management, it would be important to consider (1) the participation of other stakeholders, (2) the analysis of other competencies and (3) the analysis of other dimensions of human beings such as cognitive style, cultural influences, abilities and emotions control. This in order to encourage the initial SRI management approach.

\section{ACKNOWLEDGEMENTS}

This paper is part of the research project "Corporate entrepreneurs: analysis of socially responsible innovation from the employees' attitudes and leader's role, to complement the preliminary version of ("Inn-Cumbe") an innovation management model".

\section{REFERENCES}

Bedoya, M., Toro, I. and Arango, B. 2017. Emprendimiento Corporativo e Innovación: Una Revisión y Futuras Líneas de Investigación. Espacios, 38(17), pp.20-38.

Beije, P., 1998. Technological change in the modern economy: basic topics and new developments. Cheltenham: Edward Elgar Publishing. 
Beristain, L.M., 2009. Una revisión de la interpretación económica sobre la innovación. Journal of technology management \& innovation, [e-journal] 4(4), pp.139-149. http://dx.doi.org/10.4067/S0718-27242009000400012.

Biondi, L. and Galli, R., 1992. Technological trajectories. Futures, [e-journal] 24(6), pp.580-592. http://dx.doi.org/10.1016/0016-3287(92)90118-Y.

Bramanti, A. and Ratti, R., 1997. The multi-faced dimensions of local development. In: R. Ratti, A. Bramanti and R. Gordon, eds. 1997. The Dynamics of Innovative Regions: The GREMI Approach. Aldershot, Brookfield: Ashgate. pp.3-44.

Carroll, A.B., 1979. A Three-Dimensional Conceptual Model of Corporate Performance. Academy of Management Review, 4(4), pp.497-505.

Castrogiovanni, G.J., Urbano, D. and Loras, J., 2011. Linking corporate entrepreneurship and human resource management in SMEs. International Journal Of Manpower, [e-journal] 32(1), pp.34-47. http://dx.doi.org/10.1108/01437721111121215.

Cámara de comercio de Medellín para Antioquia, 2013. Revista Antioqueña de Economía y Desarrollo. [pdf] Medellín: Cámara de comercio de Medellín para Antioquia. Available at: <http://www.camaramedellin.com.co/site/Bibliotecavirtual/Estudios-economicos/Revista-Antioquena-de-Economia-y-Desarrollo-

RAED/Revista-Antioquena-de-Economia-y-Desarrollo-6.aspx> [Accessed 18 February 2016].

Cooper, R.G. and Cooper, R.G., 2003. Profitable Product Innovation: The Critical Success Factors. In: L.V. Shavinina, ed. 2003. The International Handbook on Innovation. Oxford: Elsevier. pp.139-157. http://dx.doi.org/10.1016/b978-008044198-6/50010-3.

Corbett, A., Covin, J.G., O'Connor, G.C. and Tucci, CH.L., 2013. Corporate Entrepreneurship: state-of-the-art research and a future research agenda. Journal of Product Innovation Management, [e-journal] 30(5), pp.812-820. http://dx.doi.org/10.1111/jpim.12031.

Creswell, J.W., Klassen, A.C., Clack, V.L.P. and Smith, K.C., 2011. Best practices for mixed methods research in the health sciences, Office of behavioral and social sciences research national institutes of health. Washington, DC: NIH Office of Behavioral and Social Sciences Research.

DANE, 2015. Encuesta de desarrollo e innovación tecnológica - EDIT (industria manufacturera 2013 - 2014). [pdf] Available at: $<$ http://www.dane.gov.co/files/investigaciones/boletines/edit/presentacion_EDIT _manufacturera_2013_2014.pdf> [Accessed 22 February 2016].

Dodgson, M., 1993. Technological collaboration in industry: Strategy, policy and internationalisation in innovation. London: Routledge. 
Dodgson, M. and Bessant, J.R., 1996. Effective innovation policy: A new approach. London: International Thomson Business Press.

Dosi, G., 1982. Technological paradigms and technological trajectories: A suggested interpretation of the determinants and directions of technical change. Research Policy, [e-journal] 11(3), pp.147-162. http://dx.doi.org/10.1016/00487333(82)90016-6.

Dosi, G., 1988. Sources, Procedures , and Microeconomic Effects of Innovation. Journal of economic literature, 26(3), pp.1120-1171.

Dosi, G. and Egidi, M., 1991. Substantive and procedural uncertainty, An exploration of economic behaviours in changing environments. Journal of Evolutionary Economics, [e-journal] 1(2), pp. 145-168. http://dx.doi.org/10.1007/BF01224917.

Dowrick, S., 1995. Economic approaches to innovation. Aldershot: Edward Elgar Publishing.

Escobar-Sierra, M., 2015. Análisis de la gestión de la innovación vinculada con la responsabilidad social desde las dimensiones motivación y conocimiento: un estudio de caso. Ph. D. Universidad Nacional de Colombia. Available at: $<$ http://www.bdigital.unal.edu.co/51034/1/1128270682.2015.pdf $>$ [Accessed 22 February 2016].

Escobar-Sierra, M. and Vera-Acevedo, L.D., 2016. "Inn-Cumbe": un modelo para la gestión de la innovación socialmente responsable, propuesto a partir de un estudio de caso a nivel organizacional. Espacios, 37(17) [online] Available at: $<$ http://www.revistaespacios.com/a16v37n17/in163717.html> [Accessed 22 February 2016].

Feldman, M.P., 1994. The Geography of Innovation. Dordrecht: Springer.

Florida, R., 1995.Toward the learning region. Futures, [e-journal] 27(5), pp.527536. http://dx.doi.org/10.1016/0016-3287(95)00021-N.

Freeman, C., 1982. The Economics of Industrial Innovation. $2^{\text {nd }}$ Ed. London: Printer.

Freeman, C., 1991. Networks of innovators: a synthesis of research issues. Research Policy, [e-journal] 20(5), pp.499-514. https://doi.org/10.1016/00487333(91)90072-X.

Freeman, C. and Perez, C., 1988. Structural crises of adjustment, business cycles and investment behaviour. In: D. Preece, I. McLoughlin and P. Dawson, eds. Technology, Organizations and Innovation: Theories, concepts and paradigms. London: Pinter. pp.38-66.

Gann, D.M., 2003. Building innovation: Complex constructs in a changing world. London: Thomas Telford Publishing. 
Guadamillas, F. and Donate, M.J., 2008. Responsabilidad social corporativa, conocimiento e innovación: hacia un nuevo modelo de dirección de empresas. Revista europea de dirección y economía de la empresa, 17(3), pp.11-26.

Hadjimanolis, A., 2003. The barriers approach to innovation. In: L.V. Shavinina, ed. 2003. The international handbook on innovation. Oxford: Elsevier. pp.559573.

Hashimoto, M. and Nassif, V.M.J., 2014. Inhibition and encouragement of entrepreneurial behavior: antecedents analysis from managers' perspectives. BAR - Brazilian Administration Review, [e-journal] 11(4), pp.385-406. http://dx.doi.org/10.1590/1807-7692bar2014130008.

Hobday, M., 1991. Dynamic networks, technology diffusion and complementary assets: Explaining U.S. decline in semiconductors. Falmer: Science Policy Research Unit, University of Sussex.

Honkasalo, A., 2000. Eco-efficiency, Entrepreneurship and co-operation: the finnish environmental cluster research programme. In: OECD, ed. 2000. Innovation and the Environment. Paris: OECD. pp.137-142.

Jardón, C.M., 2011. Innovación empresarial y territorio: una aplicación a Vigo y su área de influencia. Eure (Santiago), [e-journal] 37(112), pp.115-139. http://dx.doi.org/10.4067/S0250-71612011000300006.

Keeble, D., 2000. Collective Learning Processes in European High-Technology Milieux. In: D. Keeble and F. Wilkinson, eds. 2000. High-technology Clusters, Networking and Collective Learning in Europe. Aldershot: Ashgate. pp.199-229.

Kirat, T. and Lung, Y., 1999. Innovation and proximity. Territories as loci of collective learning processes. European Urban and Regional Studies, [e-journal] 6(1), pp.27-38. http://dx.doi.org/10.1177/096977649900600103.

Kline, S.J. and Rosenberg, N., 1986. An overview of innovation. In: R. Landau and N. Rosenberg, eds. 1986. The Positive Sum Strategy: Harnessing Technology for Economic Growth. Washington: National Academy Press. pp.275-305.

Klonoski, R.J., 1991. Foundational considerations in the corporate social responsibility debate. Business Horizons, 34(4), pp.9-19.

Lau, T., Shaffer, M., Chan, K.F. and Man, T.W.Y, 2012. The entrepreneurial behaviour inventory: A simulated incident method to assess corporate entrepreneurship. International Journal of Entrepreneurial Behavior \& Research, [e-journal] 18(6), pp.673-696. http://dx.doi.org/10.1108/13552551211268120.

Lawson, C., 2000. Collective learning, system competences and epistemically significant moments. In: D. Keeble and F. Wilkinson, eds. 2000. Hightechnology Clusters, Networking and Collective Learning in Europe. Aldershot: Ashgate. pp.182-198. 
Longhi, C. and Keeble, D., 2000. High-tech clusters and collective learning in Europe: regional evolutionary trends in the 1990s. In: D. Keeble and F. Wilkinson, eds. 2000. High-technology Clusters, Networking and Collective Learning in Europe. Aldershot: Ashgate. pp.21-56.

Lundvall, B.-А., 1992. National systems of innovation: Towards a theory of innovation and interactive learning. London: Pinter.

Macleod, G., 1996. The cult of enterprise in a networked, learning region? Governing business and skills in lowland Scotland. Regional Studies, [e-journal] 30(8), pp.749-755. http://dx.doi.org/10.1080/00343409612331350038.

Marceau, J., 1992. Reworking the World: Organisations, Technologies, and Cultures in Comparative Perspective. Berlin: De Gruyter studies in organization.

Marinova, D. and Phillimore, J., 2003. Models of innovation. In: L.V. Shavinina, ed. 2003. The international handbook on innovation. Oxford: Elsevier. pp.44-53.

McFadzean, E., O'Loughlin, A. and Shaw, E., 2005. Corporate entrepreneurship and innovation part 1: the missing link. European Journal of Innovation Management, [e-journal] 8(3), pp.350-372. http://dx.doi.org/10.1108/14601060510610207.

Méndez, R., 2002. Innovación y desarrollo territorial: algunos debates. Revista EURE, [e-journal] 28(84), pp.63-83. http://dx.doi.org/10.4067/S025071612002008400004.

Merton, R.K., 1973. The Sociology of Science: Theoretical and Empirical Investigations. Chicago: University of Chicago Press.

Metcalfe, J.S., 1995. Technology systems and technology policy in an evolutionary framework. Cambridge Journal of Economics, [e-journal] 19(1), pp.25-46. https://doi.org/10.1093/oxfordjournals.cje.a035307.

Morgan, J.N. and Sonquist, J.A., 1963. Problems in the analysis of survey data and a proposal. Journal of the American Statistical Association, 58(302), pp.415434.

Nelson, R.R. ed., 1993. National innovation systems: a comparative analysis. New York: Oxford University Press, USA.

Nelson, R.R., 2000. National innovation systems. In: Z.J. Ács, ed. 2000. Regional Innovation, Knowledge and Global Change. London: Pinter. pp.11-26.

Parslow, R.A., Christensen, H., Griffiths, K.M. and Groves, CH. 2006. The warpy thoughts scale: a new 20-item instrument to measure dysfunctional attitudes. Cognitive behaviour therapy, [e-journal] 35(2), pp.106-16. https://doi.org/10.1080/16506070500372279.

Pavitt, K., Robson, M. and Townsend, J., 1989. Technological Accumulation, Diversification and Organisation in UK Companies, 1945-1983. Management Science, 35(1), pp.81-99. 
Perez, C., 1983. Structural Change and Assimilation of New Technologies in the Economic and Social Systems. Futures, [e-journal] 15(5), pp.357-375. https://doi.org/10.1016/0016-3287(83)90050-2.

Pernelle, P., Carron, T., Elkadiri, S., Bissay, A. and Marty, J.-C., 2014. PLM serious game approach available both for change management and knowledge assessment. In: S. Fukuda, A. Bernard, B. Gurumoorthy and A. Bouras, eds. 2014. Product Lifecycle Management for a Global Market. PLM 2014. IFIP Advances in Information and Communication Technology. Berlin, Heidelberg: Springer. pp.323-332. https://doi.org/10.1007/978-3-662-45937-9_32.

Porter, M.E., 1990. The Competitive Advantage of Nations. New York: The Free Press.

Programa de Transformación Productiva, 2015. Sector industrial autopartes y vehiculos. [online] Available at: <http://ptp.amagi4all.com/informacionestadistica/industria-autopartes/autopartes-produccion $>$ [Accessed 22 February 2016].

Reinig, B.A. and Briggs, R.O., 2013. Putting quality first in ideation research. Group decision and negotiation, [e-journal] 22(5), pp.943-973. https://doi.org/10.1007/s10726-012-9338-y.

Rodríguez, M.J. and Mora, R.C. eds., 2001. Estadística informática: casos y ejemplos con el SPSS. Alicante: Universidad de Alicante.

Rosenberg, N., 1976. Perspectives on Technology. New York: Cambridge University Press.

Rosenberg, N., 2000. Schumpeter and the Endogeneity of Technology: Some American Perspectives. London: Routledge.

Rothwell, R., 1992. Successful industrial innovation: critical factors for the 1990s. R\&D Management, 22(3), pp.221-239.

Rothwell, R. and Zegveld, W., 1985. Reindustrialization and Technology. New York: M.E. Sharpe.

Sahal, D., 1981. Patterns of technological innovation. New York: AddisonWesley Publishing Company.

Sako, M., 1992. Prices, Quality and Trust: Inter-firm Relations in Britain and Japan. Cambridge: Cambridge University Press.

Schumpeter, J.A., 1983. The theory of economic development. New Jersey: Transaction Publishers.

Schwartz, M.S. and Carroll, A.B., 2003. Corporate social responsibility: a threedomain approach. Business ethics quarterly, [e-journal] 13(4), pp.503-530. https://doi.org/10.2307/3857969. 
Shaw, E., O’Loughlin, A. and McFadzean, E., 2005. Corporate entrepreneurship and innovation part 2: a role $\square$ and process $\square$ based approach. European Journal of Innovation Management, [e-journal] 8(4), pp.393-408. https://doi.org/10.1108/14601060510627786.

Simmie, J. ed., 1997. Innovation Networks and Learning Regions?. London: Jessica Kingsley Publishers.

Teece, D.J., 2002. Managing intellectual capital: organizational, strategic, and policy dimensions. New York: Oxford University Press.

Urbano, D., Toledano, N. and Ribeiro-Soriano, D., 2011. Prácticas de gestión de recursos humanos y desarrollo de nuevos proyectos innovadores: Un estudio de casos en las PYMEs. Universia Business Review, 29, pp.116-130.

Vieira, E.R., Alves, C. and Duboc, L., 2012. Creativity patterns guide: support for the application of creativity techniques in requirements engineering. In: M. Winckler, P. Forbrig, and R. Bernhaupt, eds. 2012. Human-centered software engineering. Berlin: Springer. pp.283-290.

Wolmarans, S. and Martins, N., 2001. The 360 degree emotional competency profiler. Johannesburg: Organisational Diagnostics and Learning Link International.

Yin, R.K., 1992. The case study method as a tool for doing evaluation. Current Sociology, [e-journal] 40(10), pp.121-137. https://doi.org/10.1177/001139292040001009.

Yin, R.K., 2002. Case study research: design and methods. Applied Social Research Methods Series, Vol 5. 3rd Ed. Thousand Oaks, CA, US: Sage publications.

\section{ABOUT AUTHORS}

Mauricio Bedoya-Villa, Ms.C. - Faculty of Economics and Administrative Sciences, University of Medellin, Carrera 87 No. 30 - 65, Block 7, Office 111, Medellin, Colombia, e-mail: mbedoya@udem.edu.co. Author's ORCID: https://orcid.org/0000-0002-3093-0503.

Manuela Escobar-Sierra, Ph.D. - Faculty of Economics and Administrative Sciences, University of Medellin, Carrera 87 No. 30 - 65, Block 12, Office 101, Medellin, Colombia, e-mail: manuelaescobar@gmail.com. Author's ORCID: https://orcid.org/0000-0003-1865-6238.

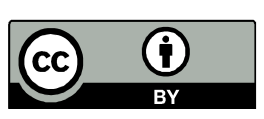

(C) 2018 by the authors. Submitted for possible open access publication under the terms and conditions of the Creative Commons Attribution (CC-BY) license (http://creativecommons.org/licenses/by/4.0/). 